\title{
Information Communication Technology as a Determinant of the FDI Flows
}

\author{
PhD. Candidate Florida Veljanoska
}

International University of Struga

\author{
MSc. Candidate Majlinda Axhiu
}

International University of Struga

MSc. Mirlinda Husejni

\author{
Doi:10.5901/mjss.2013.v4n11p218
}

\begin{abstract}
The flows of global FDI have increased substantially in the recent years. Many developing countries have improved living conditions, thanks to the great inflow of FDI. Everybody agrees that the effects from FDI inflows are positive and generate strong economic impulses through the economy of the country receiver. Those effects make the countries compete each other to win more foreign capital. That is why many studies are dedicated on exploring the determinants of FDI flows. The policy makers need to know what makes markets attractive for foreign companies and how each factor impact on FDI inflows. The main subject of this paper is exploring the impact of ICT on FDI inflows. In the frame of the effort it will be analyzed the data from many developing as well as developed countries. It will be made a comparative analyze of the level of the ICT in a certain country, with the level of the FDI inflows. According to the findings in this paper there is a significant correlation between the FDI inflows and the level of ICT development, which means that the foreign investors consider ICT as important factor that determines FDI location. The findings also suggest that the correlation is more intensive when foreign companies invest in high-tech sector, than in labor intensive sectors. The findings can be use by policy creators in their efforts to make more attractive clime for FDI. Only by knowing what foreign investors are looking for, the country can become a home for many MNC.
\end{abstract}

Keywords: Foreign direct investment, Information - communication technology, developed and developing countries

\section{Introduction}

In the last two decades we are witnessing the great inflows of foreign direct investments (FDI) towards the developing countries. However, the distribution of the FDI inflows is not equally distributed among the developing and transition economies. While part of them enjoys the benefits from FDI inflows, others are still struggling to find the way to attract foreign investment capital, in order to bridge the investment gap.

The fact that the FDI inflows are not equally distributed among developing countries shows that some countries are more attractive for foreign investors, than the others. This fact demonstrates that some economies have more favorable investment conditions, than others. It also shows that there are some factors, which have positive or negative influence on FDI flows.

If we consider that FDI inflows are the best and painless way for obtaining investment capital and have great impact on the development, it becomes clear why almost all developing countries are "fighting" for more FDI. Namely, the policy makers in developing countries continually introduce many measures in order to increase the level of FDI inflows. Some of them have given successful results and some have failed in delivering the expected outcome. That is a proof that not all policy makers are aware of the real determinants of the FDI flows and the importance of each factor. It does not occur rare when officials spend plenty of money in order to increase the level of FDI inflows, but never get the projected effects. Surely the reason is in faulty quantification of each FDI determinant, individually and collectively. Namely, the relative importance of FDI determinants has changed over time, and even though the importance of the traditional determinants has not disappeared with the globalization, their relevance is on decline.

Unfortunately, the focus of existing literature on FDI was on traditional FDI determinants, such as market seeking factors, natural resources, low cost and favorable investment conditions, and few authors have considered the importance of the information communication technologies (ICT), as a determinant of the FDI inflows. The authors in the 
past have devoted limited attention to this determinant, although it is understandable that nowadays ICT plays vital role in almost all business processes, and in the same time has changed the way in which these processes are handled. Unfortunately, ICT as a FDI determinant unjustified got very little attention from the experts, and as a result of that, got little attention from the policy makers, as well.

The aim of this paper is to fill the gap in existing literature by identifying the importance of the level of domestic technological capabilities and quality of IT based facilities in explaining the pattern of FDI inflows to the developing countries. Namely, this paper provides a special contribution to FDI theory, by focusing on technology, particularly ICT, an area of increasing importance in the global competition.

In order to get qualitative results, we have used broad range of statistical methods, as well as descriptive, analytic - synthetic, comparative and historical methods. We have also used tables and charts for better visual presentation of the results, so that the reader can get qualitative understanding of the data that are shown in the paper.

The paper is organized in three sections. In the first section we will give theoretical explanations about the meaning of FDI and its' effects. In the second section we will focus our analysis on FDI determinants, with a special emphasis on ICT and in the final section is shown the analysis about the correlation between FDI inflows and ICT.

\section{Why are FDls so important for developing countries}

Almost all developing countries are facing the shortage of capital for investment and are forced to obtain foreign capital in order to bridge the investment gap. Even though foreign capital can enter in different forms, the most preferred form is as direct investment. FDI has many advantages over the other forms of foreign investments, such as foreign loans, and even grants (which occur consanguineous, and are not often correlated with investment in real sector). That is exactly why the countries and their governments fight each other in order to attract more inflow of FDI. There are many studies which explain why countries compete with each other for more FDI. Here, we will try to summarize the overall FDI benefits, according to the majority of the experts.

According to EUROSTAT ${ }^{1}$, the most important benefits from FDI inflows for the country - receiver of FDI, are:

- Improving the balance of payment position through the initial investment, but also through the expected export growth.

- Economic development of the country, job creation, improving the quality and efficiency of the production, development of the local companies.

- Transfer of technology, managerial knowledge and skills.

Probably, the best presentation of the FDI benefits was given by Tomas Dudas. ${ }^{2}$ According to him:

- Long-term capital is the best for long-term development. FDI obtain such capital in countries which face shortage of it.

- Foreign investors support development projects in a better and cheaper way.

- Foreign corporations create new jobs.

- FDI brings new technologies, which otherwise are inaccessible for developing countries. There are some empirical studies which proof that there is a "spread effect" outside the foreign company.

- Foreign companies have better access to international markets, which can be useful relations for the home subcontractors.

- Foreign companies usually bring knowledge, including managerial knowledge and skills. The studies suggest that there is a "spread effect", when the employees change the job, and use the accumulated knowledge.

- "Crowding effect" - the entrance of one foreign company, usually brings other foreign companies (commonly subcontractors).

- Foreign companies improve the business clime in the country - receiver, through the implementation of the business ethics and managerial rules.

- FDls usually carry new "clean" technology.

- FDls usually provoke an increase in the salary level.

- FDls have positive effect on a country's balance of payment.

Although there are some side effects from FDI inflows, their influence is far below the positive effects, and does

${ }^{1}$ EU FDI Yearbook 2008, EUROSTAT, 2009

2 Tomas Dudas, "The possible positive and negative effect of FDI inflows", University of economics in Bratislava, vidi: http://fmv.euba.sk/index-en.html 
not reduce the overall image about the real importance of the FDI inflows for the developing countries. That is why policy makers are interested in exploring the main determinants of the FDI flows. In the next section we will focus our analysis on the main determinants of the FDI inflows, with a special emphasis on the correlation between FDI and ICT.

\section{The determinants of the FDI flows}

\subsection{Literature rewiev about the FDI determinants}

Although there are many studies about the FDI determinants, most of them did not take into account the fact that the globalization has changed the relative importance of each FDI factor, and that there are other determinants which now define the location of multinational companies (MNC). In the most of the previous studies the authors have found that the FDI location is mostly determined by market - seeking factors, or by location advantages, such as natural resources, low wages, low tariffs, easy of doing business etc. In the following part we will elaborate the main determinants of the FDI flows, according to some experts, as well as according to our opinion.

The majority of the USA literature found that the main determinants of the American direct investment abroad were:

- Market related factors, such as market size, population, growth rate, level of saving (Bachi \& Wheeler, 1989, McConnel 1980, Mandell \& Killian 1974, Arpan \& Ricks 1995).

- Resource seeking factors, such as work force, level of salaries, level of work force education, etc. (Little 1978, Glickman \& Woodward 1988, Mandell \& Killian 1974, Arpan \& Ricks 1995).

- Factors correlated with policy and regulative, including government support, public expenses, taxation, level of development, etc.

There are also some researches about the FDI determinants, which were accomplished in Great Britain. Here we will show some of them:

- Market related factors, such as infrastructure investment (Hill \& Munday 1997) and the population (Billington) were very important in attracting FDI to Great Britain.

- According to Billington (1999) high level of unemployment and work force availability have positive impact on FDI inflow.

- According to Billington (1999) foreign investors are searching for efficiency. Hill and Munday $(1991,1992)$ state that implementation of preferential government policies, as well as high expenses for infrastructure have positive influence on FDI inflows. (Hill \& Munday 1991, 1992).

There is also an interesting research about the determinants of the FDI inflows towards the transition economies. Namely, Lankes \& Venables (1996) found that foreign investors in these countries were mostly attracted by market searching factors. They also state that after a part of them were integrated into the European Union; the main determinant became the low cost of production for export (export-oriented). They suggest that the importance of natural resources should not be neglected, also.

According to Palit et.al.(2007) the main determinants of the FDI inflows towards the region of developing Asia and India were: ${ }^{3}$

- Economic factors - host country market size, availability and cost of skilled labor, exchange rate, stability, availability of resources, infrastructure, etc.

- Host country policies - outward orientation, tax rates, and investment incentives.

- Institutional factors - political stability, ease of doing business, cultural differences from host country, language, etc.

A group of authors considered that FDI inflows into the developing countries were negatively affected by political instability and uncertainties. Dunning (2005) found that FDI in developing countries has shifted from market and resource seeking to efficiency seeking.

On the base of all previously mentioned findings about the FDI determinants, it becomes clear that the majority of experts did not take into account the fact that globalization has provoked many changes in the global economy, including in the determinants of the FDI flows. It is indigestible how the authors neglect one of the main achievements in the recent history - ICT. Namely, ICT has changed the way in which business is handled, as well as the way in which investors perceive the investment clime. So, more emphasis should be put on the importance of the ICT as a determinant of the

${ }^{3}$ A. Palit et.al., "Technological Capabilities as a Determinant of FDI inflows: Evidence from Developing Asia and India", Working paper No.193, April 2007 
FDI location. In the next part we will elaborate about the correlation between FDI flows and ICT.

\subsection{ICT as a FDI determinant}

As we already mentioned, one of the most developed phenomena in the recent history is ICT. Specifically, ICT has changed the way in which people and companies operate, do their everyday activities, do business, etc. So, it is expectable that new information technologies have changed the way in which foreign investors perceived good investment clime and make a decision about investment location.

ICT is a composite variable defined by indicators, such as density of internet hosts, number of computers, fixed and mobile telephones, fax machines, TV sets, subscribers to newspaper, number of skilled information communications experts, etc. Commonly the authors measure the level of ICT development in a certain country by "ICT development index", which is defined by "International Telecommunication Union". The index is a composite value created by combining 11 indicators into one benchmark value.

In order to explore whether the ICT determines or not, the decision about the investment location, we will mention some potential benefits from new ICT. Namely, ICT is essential for growth, and is crucial for development of the countries' productive capacity in all sectors of economy. ICT links a country with the global economy and ensures competitiveness, also. It is seminal to innovations, invention and wealth creation. The main ICT benefits are reduced transport costs, improved marketing information and increased efficiency of industrial production. It is broadly acceptable that ICT encourages FDI by reducing the perceived geographic distance between home and host countries. This is understandable if we consider that distance is an important impediment of FDI due to the high communication costs of sharing information, knowledge and other intangible assets within multinational corporations (MNCs). Modern information technologies also provide more efficient way for monitoring the affiliates abroad, which is highly important for success of the businesses abroad.

ICT influences FDI inflow, mainly in two ways:

- It reduces time and expenses needed for exchanging information through all possible channels.

- It partly defines the volume of communication costs, because it determines how much the company should pay in order to be connected to the global network.

Although there are not many investigations about the relations between FDI inflows and the level of ICT development, the ones that were executed show that ICT encourages FDI by reducing perceived distance. The evidence also suggests that poor ICT development is a huge obstacle for more FDI inflows in developing countries. Explicitly, unlike developed countries where already exists a well built up ICT capacity which provoke inflow of FDI, in developing countries ICT must be built up, in order to attract more FDI. Developing countries may face opportunity costs if they delay better access and use of modern information infrastructure and information technology. They may find themselves in a low equilibrium trap because they will not be in a position to attract more FDI. So, more assistance should be given to developing countries to help them adopt ICT and to break out of their present low ICT equilibrium "trap".

The previously conducted researches, verify our expectations that ICT has positive influence on FDI inflows, and that it becomes serious determinant of the foreign affiliates location. According to Botrich (2006) ICT variables have a positive influence on the FDI stocks. He found that on the overall level the countries that were able to accumulate more FDI, were at the same time those that can offer better infrastructure in comparison with their competitors. ${ }^{4}$ Empirical evidence from the analyzes conducted in the recent FDI literature suggest that ICT infrastructure is important in attracting FDI flows (Gani \& Sharma, 2003, Choi et.al., 2008, Reynolds et.al., 2004). Addison and Heshmati (2003) argue that the spread of ICT is one of the new global determinants of FDI towards the developing countries. Veeramacheni et.al found that insufficient availability of ICT services is an inhabitant factor for economic growth, but also for attracting FDI and involvement in increasing competitive global markets.

We saw that generally, previously conducted studies agree that there is a strong correlation between FDI flows and ICT, and that well developed ICT encourages FDI inflows. Although we agreed with such interaction, we also have to mention some limitations of such statements. Some experts suggest that though ICT is a very important determinant of the FDI flows in the recent time, it is not sufficient alone to bring more FDI inflows. They also suggest, and we agree with such statements, that the level of the countries' development determine how much is ICT relevant as a FDI factor. According to Jeon et.al., ${ }^{5}$ empirical evidence shows that ICT has a more remarkable impact on FDI activities from G7 to

${ }^{4}$ V. Botrich, et. al., "Main determinants of FDI in the Southeast European Countries", Transition Study Review, 2006

${ }^{5}$ B.N. Jeon, et.al., "Information technology and Bilateral FDI, Theory and Evidence", Journal of Economic integration 
OECD countries, compared to non OECD countries. That is clear considering the fact that the main factors which make a developing country attractive for foreign investors are low wage, low tax, natural resources, favorable investment policies, which are crucial for labor intensive sectors.

Even though, ICT is extremely important for FDI inflows in advanced countries, it is not sufficient for making a country an attractive FDI destination. The importance of other FDI determinants should not be neglected, also.

In order to explore whether ICT and FDI interact between each other in the following section we will accomplish an analysis about the correlation between the level of ICT development and FDI flows.

\section{Correlation between FDI flows and ICT}

Our expectations are that well developed technological capabilities are strong FDI determinant for developed countries, but they also influence the FDI flows into the developing countries, even though with smaller intensity. At the beginning of the analysis we would also like to mention that the intensity of ICT technology impact depends from the sectors in which FDI are canalized. Namely, labor intensive investments are far less determined of ICT development, than investments in high-tech industry.

However, regarding this issue we should also mention that the connection between ICT and FDI is two sided. Namely, FDls are attracted by well developed information communication technology, but at the same time FDIs bring technological development into developing countries.

Even though we said that ICT as a FDI determinant is less important in developing countries, than in advanced economies, the cases of India and China prove the opposite. In the next part we will investigate the case of India and China in order to explore how ICT impact on FDI inflows in both countries.

\subsection{ICT as a determinant of the FDI inflows in india}

According to World Bank and IMF, India is included in a group of poor countries, eligible for IDA support. In the same time India is ranked in $104^{\text {th }}$ place according to Human Development Index, and so there is not any doubt that we are talking about the country which belongs to "third world". In spite of that, India is an emerging economy, which continuously reached among the highest growth rate in the last decade, and received a great part of the global FDI. It is true that other countries, called "Asian Tigers" have achieved an increase in FDI, also, but unfortunately that trend does not exist any longer, while in India there is still an upward FDI trend.

Although there are many explanations why FDIs in India have different trend, the main distinction is in the achieved technological development. Namely, if we analyze the level of technological development in the different economies from developing Asia, we can explain why some of them have remained as attractive FDI destinations, while others have fallen behind. The more "mature" Asian "Tigers" - Hong Kong, Korea, Singapore, China and India continue to be the top destination for FDI, while the new "tigers" - Indonesia, Malaysia, Thailand and Philippines are not any long.

Traditionally, East and Southeast Asian economies offered low-cost labor, as a "pull" factor for attracting FDI in large scale, labor intensive export oriented sectors. However, with production process becoming more complex and technology intensive, domestic technological capabilities, particularly innovative capacities, along with the ability to apply such innovations, have become more important the location advantage, than cheap labor. So, the countries which did not exploit in time the possibilities of new tech opportunities, failed to attract FDI on long range.

Technological capabilities, particularly research and development (R\&D) driven innovations capacities are a major attracting FDI factor in India. Indeed this attribute along with the progress in implementation of ICT - based techniques in business operations, provokes great change in the nature of the FDI inflows in India, from market-seeking, to the exportoriented FDI. And not only India, the case of Singapore and Republic of Korea clearly indicates that countries which were able to attract large amount of FDI, are at the same time countries that possess well-qualified and skilled technological labor.

In order to get better understanding about the interconnection between ICT and FDI in India, first we need to explore the level of ICT development in India. We will use the data about India's software export, as an indicator for the level of ICT development in the country. In the figure 1 is shown India's software export in the period 1995 -2007. 
Figure 1. India's software export in the period 1995-2008

\begin{tabular}{|c|c|c|c|}
\hline \multicolumn{4}{|c|}{ Software Services Exports of India(US \$ millica) } \\
\hline Year & $\begin{array}{l}\text { IT Services } \\
\text { Exports }\end{array}$ & ITES-BPO Exports & $\begin{array}{l}\text { Total Software } \\
\text { Services Exports }\end{array}$ \\
\hline $1995-96$ & 754 & - & 754 \\
\hline $1999-00$ & 3,397 & 565 & 3,962 \\
\hline $2000-01$ & 5,411 & 930 & 6,341 \\
\hline $2001-02$ & 6,061 & 1,495 & 7,556 \\
\hline 2002.03 & 7,100 & 2,500 & 9,600 \\
\hline 2003.04 & 9,200 & 3,600 & 12,800 \\
\hline $2004-05$ & 13,100 & 4,600 & 17.700 \\
\hline 2005.06 & 17,300 & 6,300 & 23,600 \\
\hline $2006-07$ & 22,900 & 8,400 & 31,300 \\
\hline $2007-08$ & 29.400 & 10,900 & 40,300 \\
\hline
\end{tabular}

Source: National Association of Software and Services Companies

The figure shows that there is a strong increase in software services export in India, and as a result of that in its global market share. The country now has more than $5 \%$ share in global high tech market, and has improved its position as technologically advanced economy.

Now, we will present a figure with the data about the FDI inflows towards India.

Figure 2. FDI inflows in India in period 2000-2012

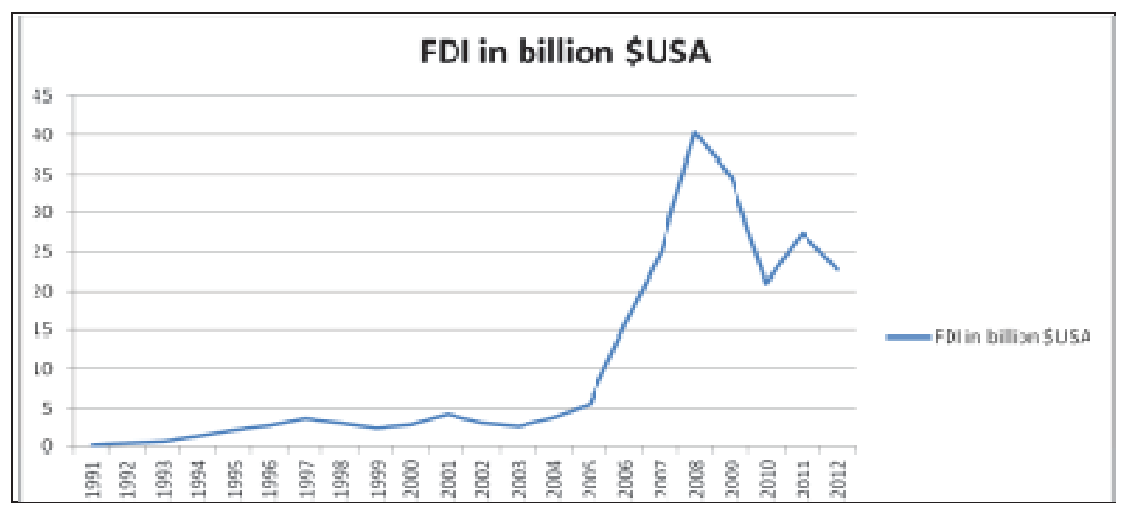

Source: http://www.economywatch.com/foreign-direct-investment

In Figure 2 is shown the trend of FDI to India in the last two decades. It is easy to conclude that there is a strong increase of FDI towards India, from neglected volume in 90 s to USA $\$ 40,4$ billion in 2008. Although there is a slight fall in the last four years, that is not a signal that something has changed regarding to FDI, but the reason is in global crisis, which hardly affected global FDI flows. It is now generally accepted that India is the second most attractive FDI destination, after China.

In order to explore the relation between ICT and FDI, now we will mention some data about the inflow of FDI in the sectors correlated with ICT. Namely, the sectional analyses show that the majority of the FDI inflows in the period 19912007 were directed to electrical equipment and services, and then followed the sector of telecommunication. After 2007 the officials in the country have modified the classification, and according to the new classification the services and computer software and hardware services are the top performers. This fact proves that FDI are directed towards high tech intensive sectors, and less towards labor intensive sectors. This fact confirms that the level of ICT development was essential, as a FDI determinant.

These data indicate that there is a strong correlation between FDI and ICT. Two facts confirm this statement. From one side there is great increase in FDI inflows, especially FDI directed toward high tech sectors, and from the other side the fact that India is ranked among the global high tech leaders. 


\subsection{ICT as a FDI determinant in China}

Instead as poor country, today China is globally recognized as "the world workshop". This epithet is valid, since Chine's export dominates in the global relations, and not only in export of labor intensive products, but as well in export of high tech products and services. According to EUROSTAT, since 2006, China has become the global leader in export of high tech products and services. Namely, the country's market share in high tech export reached $16.9 \%$ (2006), while countries, such as USA, EU - 27, Japan, stood behind. Their market share was $16.8 \%, 15 \%$ and $8 \%$, respectively. In the following years China has gone beyond these results.

All the facts, which were presented, suggest that China has become high tech giant, and that in the following years is justifiable expected to become the greatest source of high tech innovations and production.

In order to explore the relation between ICT and FDI, it is necessary to be presented the data about FDI inflows towards China. Namely, today China is the greatest absorber of the global FDIs. The latest data about the FDI inflows in China, for 2012, show that the record level of US\$116 billions, FDI inflows have been reached. Even in the years when the global crisis was on its' top, China's FDI did not fall much, and only in 2009 FDIs were below the level of US\$100 billion (USA $\$ 95$ billion).

So, the main question here is what drives the huge amount of FDls towards China. The analysis has shown that China's foreign direct investment (FDI) had experienced ceaseless changes during the past 20 years. In the 1980s they were mostly concentrated on labor-intensive industries, then in early 1990s turned to capital-intensive industries, and further in tech-intensive industries in recent years. Today, the world-leading manufacturers on PC, electronic products, telecommunication equipment, pharmaceutics, petrochemical industry, and power equipment, have expanded their production network to China. As a result of the soaring FDI in tech-intensive industries in China, China's exports on hightech production of foreign affiliates, as we already saw, has increased from US $\$ 4.5$ billions in 1996 to US $\$ 29.8$ billions in 2000 , to US $\$ 377$ billions in 2009 , accounting for 83 percent of China's total high-tech production exports, which is about $31 \%$ of China's total exports in 2009. The situation was different before. China was not a major player in the global market of high-tech products. Resource and labor intensive products have been dominating China's exports. In 1995, China accounted for a merely $2.1 \%$ of global high-tech exports. Its total exports in high-tech products were equivalent to only $8 \%$ of the US. With a 1.3 billion population, there is no surprise that China has been dominating the global market of labor intensive products. It is really a big surprise that China grew to be a top high-tech exporter within ten years.

The case with China has confirmed our statement that the relation between FDI and ICT is two sided. Namely, at the beginning low labor costs, as well as big market were the main reasons why MNCs have invested in the country. The entrance of MNCs brought new technologies, as well as know-how and managerial skills, which contributed for the improvement in the ICT development. The analysis on the ownership of the firms exporting high-tech products shows that, foreign invested firms accounted for $83 \%$ of China's high-tech exports; in particular wholly foreign owned firms dominated the sector and made up 68\%.

Now it is clear that China has grown from the country with extremely low overall tech development, to technologically highly developed economy. Today as elaborated facts show, China is the greatest technological player on the global scene. And not only that, there was a "spread effect", and now domestic firms are also technologically well developed, and have increased their share in China's high tech export. Therefore, it is FDI and outsourcing activities MNC that transformed China into a world high-tech assembling factory.

\section{Conclusion}

The analysis in the paper has shown that the level of ICT development has impact on the FDI inflows. Although the previously conducted studies suggested that ICT is determinant of the FDI flows towards developed countries, this study has proof that ICT can be a big advantage for some of the developing countries, also. Primarily the FDI toward developing countries have been attracted by low labour costs and natural resources, but lately the ICT development in the country can bring strong stimulus for further foreign investments. Only the countries, which are capable to exploit the benefits from new technologies, which were brought by foreign investors, can improve technologically, and enjoy the benefits of new high tech investment in the future.

The case with East and Southeast Asia, along with India and China has shown that only part of the countries in the region were able to exploit the benefits from the initial labour intensive foreign investments. Namely only more mature economies, including China, India, Singapore, Hong Kong, Korea, succeed to build up adequate ICT infrastructure and to become high tech giants. However, this epithet mostly belongs to China and India. Both countries are now recognized as 
the biggest exporter of high tech products and services, among developing countries. Actually, China dominates not only between developing countries, but among developed, also. Starting from 2006 China has the greatest share on the global high tech market, exceeding even USA, and exporting far more that EU-27 and Japan.

The great improvement in ICT development that has been accomplished by India and China was the reason for extremely huge increase in the FDI inflows in both countries. Actually, the level of ICT development explains why some of the previously attractive Asian "tigers" remained behind while others have achieved strong success.

Overall, this study showed that ICT is very important FDI factor, because it's found that well developed ICT base reduces the perceived geographical distance, and so encourages foreign investors. ICT also, reduces the communications' cost, improves the process of sharing information between foreign affiliates, but also offers advanced opportunities for foreign affiliates.

We expect that this paper will provide a significant contribution to the theory about the FDI determinants, because it's focused on a factor which was neglected by majority of the experts. The results of the study explain why some countries failed to continuously attract sufficient amount of FDI. This study has shown that developing countries face opportunity costs if they delay greater access to and use of information infrastructure and information technology. So, in order to successfully restructure their economies, to lure foreign investors and ultimately to get and sustain competitive advantage, policy makers need to better understand that the level of ICT has huge importance for attracting future investments. The paper concludes that more assistance should be given for ICT development to developing countries if they want to break out their present "equilibrium trap" in the near future.

\section{References}

Addison, T. and Heshmati, A. (2003). The New Global Determinants of FDI Flows toDeveloping Countries: The Impacts of ICT and Democratisation. WIDER Discussion.

Arpan, J., Ricks, D. (1995). Directory of Foreign Manufacturers in the United States. Georgia, GA: Georgia State University Publishing Services Divisions.

Bagchi-Sen, S., Wheeler, J.O. (1989). A spatial and temporal model of foreign direct investment in the United States. Economic Geography.

Billington, N. (1999). The location of foreign direct investment: An empirical analysis. Applied Economics.

Botrich, V., et. al.(2006). Main determinants of FDI in the Southeast European Countries. Transition Study Review.

Choi, S., Whan, S., Samy, Y. (2008). Reexamining the Effect of Democratic Institutions on Inflows of Foreign Direct Investment in Developing Countries. Foreign Policy Analysis.(Vol.4).

Dudas, T. The possible positive and negative effect of FDI inflows. University of economics in Bratislava, available at: http://fmv.euba.sk/index-en.html

"EU FDI Yearbook 2008". (2009). EUROSTAT.

Glickman, N., and Woodward, D. (1988). The location of foreign direct investment in the US: patterns and determinants. Int. Reg. Sci. Rev.

Hill, S. And Munday, M. (1995). Foreign Manufacturing investment in France and the UK: a regional analysis of locational determinants. Tijdschfift voor Economische en Sociale Geografie

Jeon, B., et.al., Information technology and Bilateral FDI, Theory and Evidence. Journal of Economic integration.

Lankes, H.,Venables, A. (1996). Foreign direct investment in economic transition: the changing pattern of investments. The Economics of Transition, The European Bank for Reconstruction and Development. (Vol. 4(2)).

Little, J. (1978). Locational Decisions of Foreign Direct Inves-tors in the United States. New England Economic Review.

Mandell, S. Killia, C. (1974). An Analysis of Foreign Investments in Selected Areas of he United States: A Research Projecton Behalf of the New England Regional Commission. The International Center of New England.

Mc Connel. (1980). Foreign Direct Investment in the United States. Annals of the Association of the American Geographers. (Vol.70.-2).

Palit, et.al. (2007). Technological Capabilities as a Determinant of FDI inflows: Evidence from Developing Asia and India. Working paper No.193.

Reynolds, R., Kenny, C., Liu, J., Zhen-Wei. (2004). Networking for foreign direct investment: the telecommunications industry and its effect on investment. Information Economics and Policy. (Vol. 16).

Veermachaneni, B. et.al. Information Technology, FDI and Economic growth: An India Case Study.

Woodward, D.P., (1992). Locational determinants of Japanese manufacturing start-ups in the United States. Southern Economic Journal 58. 